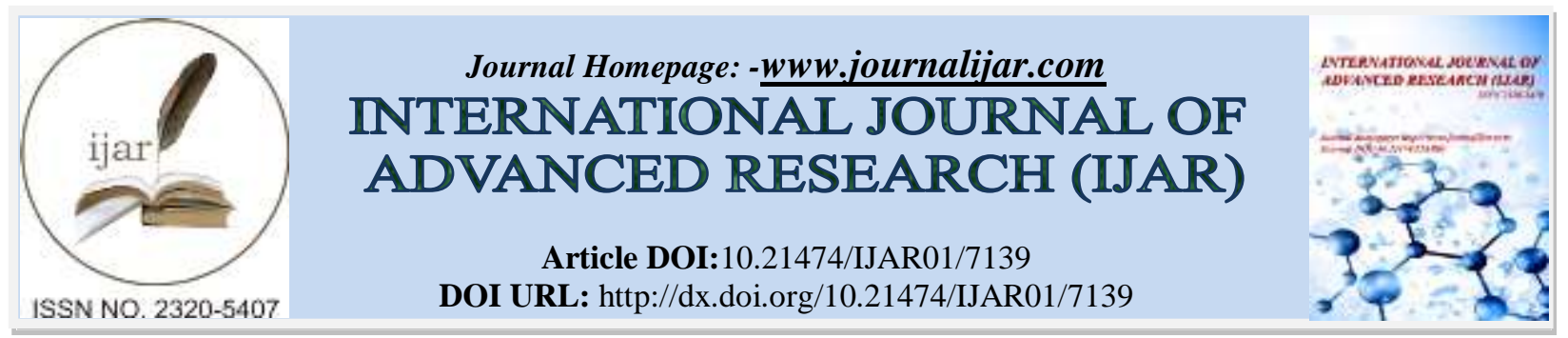

RESEARCH ARTICLE

\title{
CORIANDRUM SATIVUM: A POTENTIAL SOURCE OF THERAPEUTIC COMPOUND AGAINST CARDIOVASCULAR DISEASES.
}

\author{
Anjana Sharma ${ }^{1}$, Shweta Golhani ${ }^{1}$ and Meenal Budholia Rehman ${ }^{2}$. \\ 1. Bacteriology Laboratory, Department of P. G. Studies and Research in Biological Science, Rani Durgavati \\ University, Madhya Pradesh, India. \\ 2. Department of Botany, Mata Gujri Women's College, Jabalpur (M.P.) India.
}

\section{Manuscript Info \\ Manuscript History \\ Received: 19 March 2018 \\ Final Accepted: 21 April 2018 \\ Published: May 2018}

Keywords:-

Thrombosis, Coriander sativum, Fibrinolysis, Streptokoinase, Heparin and Phytocompounds.

\begin{abstract}
Objectives: The increasingly high incidence of cardiac diseases caused by thrombosis of the arterial vessels is one of the major factors that threaten people's health and lives around the world. Fibrinolytic agents are used to dissolve the clots in the blood vessels; however these agents have certain limitations. Herbal remedies, considered to be both safe and effective by most consumers. Coriandrum sativum has been documented as traditional treatment for cardiac diseases. Therefore, the present study was designed to investigate the effectiveness of $C$. sativum (Cor 32, Cor 75, Acr 2, RG 728, Cor 75) as a fibrinolytic agent for the treatment of cardiac diseases.

Materials and method: The fibrinolytic activity of $C$. sativum varieties (Cor 32, Cor 75, Acr 2, RG 728, Cor 75) were qualitatively determined by plate and in vitro clot lysis assay. Preliminary Phytochemical analysis of flavanoids, tannins, alkaloids, saponins, resins, carbohydrates, steroids, terpenoids and glycosides were made by following standard protocol.

Observation: The phytochemical analysis of the extract showed the presence of resins, glycosides, terpenoids, carbohydrates and flavanoids. The maximum fibrinolytic activity was showed by methanol extract of Cor 32 against the entire test compared with positive control (streptokinase and heparin) and negative control (distilled water). Thus, C. sativum of variety Cor 32 is suggested to have potential for pharmaceutical exploitation in the treatment of cardiovascular diseases.
\end{abstract}

Copy Right, IJAR, 2018,. All rights reserved.

\section{Introduction:-}

Cardiovascular diseases (CVDs) are considered as one of the leading cause of death worldwide and its burden will continue to increase due to increasing world's population and unhygienic living. By the year 2020 cardiac diseases may cause an estimated 25 million death per year (Silva et al., 2016). Blood vessels thrombus due to fibrin accumulation may leads to many cardiac diseases viz. acute myocardial infarction, ischemic heart disease, valvular heart disease, peripheral vascular diseases, arrhythmias, high blood pressure and stroke (Nascimento et al., 2015). Under balanced condition fibrin is lysed by plasmin (EC 3.4.21.7) which is activated by plasminogen activator, however in unbalanced condition as a result of pathophysiological disorder the clots are not hydrolysed and thus 
thrombus occurs (Simkahda et al., 2010). So it is important to prevent blood from clotting or to dissolve the clots in the blood streams. Thrombolytic agents like tissue plasminogen activator, urokinase, streptokinase etc. are used all over the world for the treatment. However, these agents have some limitations like excessive cost of clinical applications, undesirable side effects such as excessive bleeding and recurrence at the site of the residual thrombosis (Mahajan et al., 2010), difficulty in long-term use, low specificity to fibrin in the cases of urokinase and streptokinase, and short half-life of t-PA and urokinase. On this content searching for new fibrinolytic compound from different sources continues.

Coriander sativum L (C. sativum L; Umbelliferae) is an annual and herbaceous plant native to Mediterranean region. The major compounds present are linalool $(67.70 \%), \alpha$-pinene $(10.5 \%), \gamma$ - terpinene $(9.0 \%)$, geranyl acetate $(4.0 \%)$, camphor $(3.0 \%)$ and geraniol $(0.9 \%)$. Apart from its culinary use it is widely used for therapeutic purpose viz. hypoglycemic, anti-inflammatory and hypolipidemic analgesic and sedative, anxiolytic antimutagenic, antihypertensive, diuretic, antioxidant, antimicrobial, carminative, antispasmodic and relaxant (Mandal et al., 2015). Therefore the present study was undertaken to see fibrinolytic effect of $C$. sativum and its different variety (Shahwar et al., 2012). In this study, we undertook an in vitro screening program to asscess the fibrinolytic potential of 5 coriander varieties (Cor 32, Cor 75, Acr 2, RG 728, Cor 75). This study is also the very first report of $C$. sativum exhibiting fibrinolytic activity.

\section{Materials and Method:- Chemicals required:-}

Human fibrinogen and thrombin were purchased from Sigma Chemical Co. (St. Louis, Missouri, USA). Other chemicals and analytical reagents were purchased from Himedia, Mumbai, India.

Streptokinase (SK): The commercially available lyophilized Sk vial of 1,500000 IU per vial was used as positive control. $5 \mathrm{ml}$ of sterile distilled water was added and mixed properly. This suspenseon was used as a stock from which $100 \mu \mathrm{l}$ (30,000 I.U) was used for in vitro clot lysis assay (Prasad et al., 2007).

Blood Specimen: Whole blood $(5 \mathrm{ml})$ was drawn from healthy human volunteers $(n=10)$ without a history of oral contraceptive or anticoagulant therapy. The informed consent from all volunteers was obtained in written.

\section{Plant material:-}

The seeds of $C$. sativum varieties (Cor 32, Cor 75, Acr 2, RG 728, Cor 75) were procured from Department of Horticulture, Jawahar Lal Nehru Krishi Vishwavidyalaya, Jabalpur (M.P.). The seeds were washed and dried at room temperature and triturated with blender and stored in hermetically sealed bottles away from light and humidity until use for extract preparation (Sharma et al., 2010).

\section{Preparation of extract:-}

Aqueous extraction: $10 \mathrm{gm}$ of each air dried powder sample were placed in $100 \mathrm{ml}$ of distilled water. and boiled for $6 \mathrm{hrs}$. At intervals of $2 \mathrm{~h}$ it was filtered through eight layers of muslin cloth and centrifuged at 5,000 X g for $15 \mathrm{~min}$. The supernatant was collected and completely evaporated using water bath maintained at $40^{\circ} \mathrm{C}$ and stored in refrigerator.

Solvent extraction: Ten Grams of each air dried powdered sample were mixed with $100 \mathrm{ml}$ each of organic solvent (methanol, acetone and chloroform) and kept in rotary shaker (190-220 rpm) for $48 \mathrm{~h}$ at $37^{\circ} \mathrm{C}$. After that it was filtered through eight layers of muslin cloth to remove all residual debris and centrifuged at $5000 \mathrm{X} \mathrm{g}$ for 15 minutes. The supernatants were collected and then concentrated over water bath maintained at $40^{\circ} \mathrm{C}$. The concentrated extracts were freeze dried to remove solvent and stored in refrigerator.

The extraction yield of the extracts were expressed as-

Extraction yield $(\%)=(\mathrm{W} 1 / \mathrm{W} 2) \times 100$

Where, W1 is net weight of powder in grams after extraction and W2 is total weight of powder in grams taken for extraction.

\section{Phytochemical analysis:-}

Phytochemical analysis was carried out according to the methods of Soffowora (1993) and Harborne (1983). The extracts prepared were screened for flavanoids, tannins, alkaloids, saponins, resins, carbohydrates, steroids, terpenoids and glycosides was determined as follows. 


\section{Test for alkaloids:-}

$0.2 \mathrm{~g}$ of extracts was shaken with $1 \% \mathrm{HCl}$ for two minutes. The mixture was filtered and drops of Dragendorff's reagent added. Formation of a precipitate indicated the presence of alkaloids.

\section{Test for Saponins:-}

$0.2 \mathrm{~g}$ of extracts was shaken with $5 \mathrm{ml}$ of distilled water in a test tube. Frothing which persists on warming was taken as evidence for the presence of saponins.

\section{Test for tannins:-}

$0.2 \mathrm{~g}$ of extracts was stirred with distilled water and filtered. Ferric chloride was added to the filtrate. A blueblack, green or blue-green precipitate was taken as an evidence for the presence of tannins.

\section{Test for Steroids:-}

(Salkowski's test): $0.2 \mathrm{~g}$ of the extracts was dissolved in $2 \mathrm{ml}$ of chloroform. Concentrated sulphuric acid was carefully added to form a lower layer. A reddish-brown colour at the interphase indicated the deoxy sugar characteristics of cardenolides.

\section{Test for flavonoids:-}

A little amount of magnesium powder and few drops of concentrated hydrochloric acid were added to $3 \mathrm{ml}$ of the extracts. A red or intense red colouration indicated the presence flavonoids.

\section{Test for resins:-}

Five milliliters of copper acetate solution was added to $5 \mathrm{ml}$ of the methanolic extract. The resulting solution was shaken vigorously and allowed to separate. A green coloured solution is an evidence of the presence of resin.

\section{Test for glycosides:-}

The extracts was hydrolyzed with $\mathrm{HCl}$ solution and neutralized with $\mathrm{NaOH}$ solution. A few drops of Fehlings solution A and B were added. Red precipitate indicates the presence of glycosides.

\section{Test for carbohydrates:-}

The extract was mixed with Molisch reagent, and then added conc. $\mathrm{H}_{2} \mathrm{SO}_{4}$ along the sides of the test tube to form layers. Appearance of reddish violet ring at the interference indicated the presence of carbohydrates

\section{Test for terpenoids:-}

Extract was treated with few drops of acetic anhydride, boil and cool. Conc. sulfuric acid was added from the sides of the test tube which showed a brown ring at the junction of two layers, and formation of deep red color indicated the presence of triterpenoids

\section{Fibrinolytic activity:-}

The fibrinolytic activity of Coriander sativum varieties (Cor 32, Cor 75, Acr 2, RG 728, Cor 75) were qualitatively determined by plate assay and in vitro clot lysis assay.

\section{Fibrin plate assay:-}

Fibrinolytic activity of different extracts was determined by fibrin plate assay as described by Astrup and Mulertz method (1952). $2 \mathrm{ml}$ of $50 \mathrm{mg} / \mathrm{ml}$ of fibrinogen in $20 \mathrm{mM}$ Tris $\mathrm{HCl}$ buffer containing $0.15 \mathrm{M} \mathrm{NaCl} \mathrm{pH} 7.43$ at $55^{\circ} \mathrm{C}$ was mixed with an equal volume of $2 \%$ (w/v) agarose solution followed by addition of $40 \mu$ thrombin in a petri dish. Wells of $10 \mathrm{~mm}$ diameter, suitably distant were punched off and subsequently filled with $100 \mu \mathrm{lof}$ each extract. The streptokinase and heparin were taken as positive control, where as distilled water as negative control. The plates were incubated at $37^{\circ} \mathrm{C}$ for 12 hours for zone clearance around the well. The clearance of zone that appeared after 12 hours were measured (in $\mathrm{mm}$ ) as a property of the fibrinolytic activity of the extracts. The entire tests were performed in triplicates.

\section{Blood agar plate assay:-}

To test the fibrinolytic activity $3 \mathrm{ml}$ of whole blood was mixed with $15 \mathrm{ml}$ luke warm of agar solution poured in a sterilized petridish. Wells of $10 \mathrm{~mm}$ diameter suitably distant were punched off and subsequently filled with $100 \mathrm{ul}$ of each extract. The streptokinase and heparin were taken as positive control, where as distilled water as negative 
control. The plates were incubated for 24 hours for clear zone analysis. The clear zone after 24 hours around the well represents the fibrinolytic activity of the extracts (Sharma et al., 2017).

\section{Zone index:-}

Diameter of zone produced by extractldiameter of the well.

\section{Blood clot lysis assay:- \\ Clot lysis:-}

Clot lysis effect of the extracts of $C$. sativum was measured according to the method of Prasad et al., 2007. Briefly, venous blood drawn from healthy volunteer who had not taken any medication for last one month was transferred in different pre weighed sterile micro centrifuge tube $\left(500 \mu \mathrm{l} /\right.$ tube) and incubated at $37^{\circ} \mathrm{C}$ for $45 \mathrm{~min}$. After clot formation, serum was completely removed (aspirated out without disturbing the clot formed) and washed several times with distilled water and then each tube having clot was again weighed to determine the clot weight. Each micro centrifuge tube containing clot was properly labelled and $100 \mu \mathrm{l}$ of each extract was added to the tubes. Tube containing water along with clot serves as a negative and with streptokinase and heparin serves as positive thrombolytic control. All the micro centrifuge tube were then incubated at $37^{\circ} \mathrm{C}$ for $6 \mathrm{hrs}$ and observed for clot lysis. After incubation, fluid obtained after clot lysis was removed and micro centrifuge tube were again weighed to observe the difference in weight after clot disruption. Difference obtained in weight taken before and after clot lysis was expressed as percentage of clot lysis. The test was performed in triplicates.

Clot lysis $\%=$ (weight of clot before lysis* - weight of clot after lysis) $\mathrm{x} 100$

clot weight $=$ weight of clot containing tube - weight of tube alone.

\section{Results and Discussion:-}

C. sativum is an important medicinal spice as documented in ayurvedic pharmacopeia for variety of therapeutic properties, such as anti-inflammatory, anti-diabetic, hepatoprotective, and so on. It has recently been documented to possess anti-thrombotic activity too (Vasanthi et al., 2010). In this study five coriander varieties (Cor 32, Cor 75, Acr 2, RG 728, Cor 75) were selected for extract yield calculation, phytochemical analysis and fibrinolytic activity, however this is the first study for the evaluation of fibrinolytic activity of $C$. sativum. Extraction yield from a plant has a great effect on the overall efficacy and selection for bioprospecting and in the calculation of total activity. The organic (methanol, acetone and chloroform) and the aqueous extracts of all the $C$. sativum varieties were calculated for the yield capacity (table 1). Methanol extract of Cor 32 exhibited higher yield (25.6\%) followed by methanolic extact of Kumbraj (18.4\%). It may be due to high polarity of methanol extract which can draw high variety of plant constituents than the other solvents (Paulswamy et al., 2011). The chloroform extract of all varieties showed lowest yield of $0.4 \%-0.6 \%$. The aqueous extracts of Cor 75, $\mathrm{Rg} 728$ and Acr 2 also showed lower yields $(3.58 \%, 1.72 \%$, $1.36 \%$ respectively) followed by acetone extract. The phytochemical analysis of the extract revealed the presence of resins, glycosides, terpenoids, carbohydrates and flavanoids (table 2.). These bioactive compounds have been reported to be used by plants as a defence mechanism (Mahendra et al., 2011). However, there are reports of bacterial contaminants of plants which have plasminogen receptors that bind plasminogen. Cell surface bound plasminogen is easily activated to plasmin, which could lead to fibrinolysis (Prasad et al., 2007). Bacterial plasminogen activator: staphylokinase, streptokinase, act as cofactor molecules that contribute to exosite formation and enhance the substrate presentation to the enzyme. Staphylokinase activates plasminogen to dissolve clots, fibrin fibers that hold cells together (Rahman et al., 2013). The fibrinolytic activity of the four extracts of five $C$. sativum varieties were assayed by fibrin and blood plate method. The clearance of the zone against each extract was observed to be varied. Table 3 shows that among the 5 varieties, the methanol extract of Cor 32 exhibited the maximum zone clearance while aqueous and chloroform extract had moderate zone clearance in fibrin plate assay. Whereas all the extracts were tested against blood agar plate assay, maximum zone clearance was shown against acetone extract followed by methanol aqueous and chloroform. Streptokinase and Heparin were used as positive control and as expected presented significant fibrinolytic activity. In addition to fibrinolytic activity, the extracts were also tested in relation to their capacity to hydrolyze the blood clot, in view of investigating its potentiality as a thrombolytic agent. Addition of $100 \mu \mathrm{l} \mathrm{Sk}$ and heparin as a positive control to the clots and subsequent incubation for 90 minutes at $37^{\circ} \mathrm{C}$ showed $79.3 \%$ and $82 \%$ of clot lysis respectively. On the other distilled water treated as negative control which exhibited a negligible percentage of clot lysis (3.4\%). When clots were treated with $100 \mu$ l each of different solvents extracts (Cor 32, Cor 75, Acr 2, RG 728, Cor 75) of the test sample showed significant clot lysis activity was observed (Figure 1) in case of Cor 32 the percentage clot lysis varies from $45.9 \%$ (methanol extract) to $25 \%$ (aqueous extract), where as the acetone and chloroform extract have shown similar activity. The 
extracts prepared from distilled water have shown less activity compared to positive control. A number of studies have been conducted by various researchers to find out the herbs and natural food sources and their supplements having fibrinolytic (anticoagulant and antithrombotic) effect and there is evidence that consuming such food leads to prevention of coronary events and stroke (Khan et al., 2011, Bazzano et al., 2002).

\section{Conclusion:-}

In this study, investigation of the thrombolytic activity of $C$. sativum seeds extract was carried out using a simple and rapid in vitro clot lysis model. The results indicated clearly that methanol extract of Cor 32 variety of $C$. sativum enhanced the maximum fibrinolytic effect. From the phytochemical analysis it can be indicated that fibrinolytic activity is probably due to diversified phytoconstituents including rich sources of alkaloids, resins, glycosides, saponins, carbohydrates, flavanoids and steroids.

\section{Acknowledgement:-}

Authors are thankful to Head, Department of Post Graduate Studies and Research in Biological Science, Rani Durgavati University, Jabalpur (M.P.), India, for providing Laboratory facilities and Jawaharlal Nehru Krishi Vishwavidyalaya, Jabalpur (M.P.) for providing C. sativum sample.

Table 1:-The percentage extract yield of $C$. sativum varieties.

\begin{tabular}{|c|c|c|c|c|}
\hline \multirow{2}{*}{ C. sativum varieties } & \multicolumn{4}{|c|}{ Solvents (\%) } \\
\cline { 2 - 5 } & Acetone & Methanol & Chloroform & Aqueous \\
\hline Cor 32 & 7 & 25.6 & 0.6 & 1.6 \\
\hline Cor 75 & 6.9 & 21.6 & 0.59 & 3.58 \\
\hline Rg 728 & 6.5 & 22.3 & 0.58 & 1.72 \\
\hline Acr 2 & 6.3 & 18.4 & 0.4 & 1.36 \\
\hline Kumbraj & 6.1 & 23.2 & 0.48 & 2.1 \\
\hline
\end{tabular}

Table 2:-Phytochemical analysis of $C$. sativum varieties.

\begin{tabular}{|l|l|l|l|l|l|l|l|l|l|}
\hline $\begin{array}{l}\text { C. } \\
\text { sativum } \\
\text { varietie } \\
\text { s }\end{array}$ & $\begin{array}{l}\text { Alkaloi } \\
\text { ds }\end{array}$ & $\begin{array}{l}\text { Resin } \\
\text { s }\end{array}$ & $\begin{array}{l}\text { Glycosid } \\
\text { es }\end{array}$ & $\begin{array}{l}\text { Saponi } \\
\text { n }\end{array}$ & $\begin{array}{l}\text { Terpenoi } \\
\text { ds }\end{array}$ & $\begin{array}{l}\text { Carbohydrat } \\
\text { es }\end{array}$ & $\begin{array}{l}\text { Tanni } \\
\text { ns }\end{array}$ & $\begin{array}{l}\text { Flavanoi } \\
\text { ds }\end{array}$ & $\begin{array}{l}\text { Steroi } \\
\text { ds }\end{array}$ \\
\hline Cor 32 & - & + & + & - & + & + & - & + & - \\
\hline Cor 75 & - & + & + & - & + & + & - & + & - \\
\hline Rg 728 & - & + & + & - & + & + & - & + & - \\
\hline $\begin{array}{l}\text { Kumbr } \\
\text { aj }\end{array}$ & - & + & + & - & + & + & - & + & - \\
\hline Acr 2 & - & + & + & - & + & + & - & + & - \\
\hline
\end{tabular}

+: Positive; -: Negative

Table 3:-Plate assay for fibrinolytic activity of $C$. sativum varieties

\begin{tabular}{|c|c|c|c|c|c|c|c|c|c|}
\hline \multirow{3}{*}{$\begin{array}{c}\text { S. } \\
\text { No } \\
\text {. }\end{array}$} & \multirow{3}{*}{$\begin{array}{l}C . \text { sativum } \\
\text { varieties }\end{array}$} & \multicolumn{8}{|c|}{ Fibrinolytic activity } \\
\hline & & \multicolumn{4}{|c|}{ Fibrin agar plate (mm) } & \multicolumn{4}{|c|}{ Blood agar plate (mm) } \\
\hline & & $\begin{array}{c}\text { Methan } \\
\text { ol }\end{array}$ & Acetone & $\begin{array}{c}\text { Chlorofor } \\
\text { m }\end{array}$ & $\begin{array}{c}\text { Aqueou } \\
\text { s }\end{array}$ & $\begin{array}{c}\text { Methano } \\
\text { l }\end{array}$ & Acetone & $\begin{array}{c}\text { Chlorofor } \\
\text { m }\end{array}$ & $\begin{array}{c}\text { Aqueou } \\
\text { S }\end{array}$ \\
\hline 1 & Cor 32 & $6.5 \pm 0.04$ & $\begin{array}{l}5.4 \pm 0.0 \\
2\end{array}$ & $3.2 \pm 0.02$ & $\begin{array}{c}1.5 \pm 0.0 \\
2\end{array}$ & $\begin{array}{c}4.875 \pm 0 \\
01\end{array}$ & $\begin{array}{c}2.8 \pm 0.0 \\
2\end{array}$ & $1.9 \pm 0.02$ & $\begin{array}{c}2.5 \pm 0.0 \\
3\end{array}$ \\
\hline 2 & Cor 75 & $6.4 \pm 0.02$ & $\begin{array}{c}5.35 \pm 0 . \\
01\end{array}$ & $3.19 \pm 0.02$ & $\begin{array}{c}1.6 \pm 0.0 \\
4\end{array}$ & $4.7 \pm 0.02$ & $\begin{array}{c}2.8 \pm 0.0 \\
3\end{array}$ & $1.4 \pm 0.02$ & $\begin{array}{c}2.45 \pm 0 . \\
02\end{array}$ \\
\hline 3 & Rg 728 & $6.1 \pm 0.02$ & $\begin{array}{c}5.3 \pm 0.0 \\
2\end{array}$ & $3.1 \pm 0.02$ & $\begin{array}{c}1.4 \pm 0.0 \\
4\end{array}$ & $4.5 \pm 0.07$ & $\begin{array}{c}2.7 \pm 0.0 \\
2\end{array}$ & $1.5 \pm 0.04$ & $\begin{array}{c}2.6 \pm 0.0 \\
4\end{array}$ \\
\hline 4 & Acr 2 & $5.9 \pm 0.02$ & $\begin{array}{c}5.39 \pm 0 . \\
03\end{array}$ & $3.21 \pm 0.02$ & $\begin{array}{c}1.3 \pm 0.0 \\
2\end{array}$ & $4.1 \pm 0.03$ & $\begin{array}{c}2.9 \pm 0.0 \\
2\end{array}$ & $1.8 \pm 0.20$ & $\begin{array}{c}2.51 \pm 0 . \\
03\end{array}$ \\
\hline
\end{tabular}




\begin{tabular}{|c|c|c|c|c|c|c|c|c|c|}
\hline $\mathbf{5}$ & Kumbraj & $5.8 \pm 0.04$ & $\begin{array}{c}5.41 \pm 0 . \\
03\end{array}$ & $3.18 \pm 0.01$ & $\begin{array}{c}1.39 \pm 0 . \\
02\end{array}$ & $4.2 \pm 0.01$ & $\begin{array}{c}2.45 \pm 0 . \\
01\end{array}$ & $1.9 \pm 0.01$ & $\begin{array}{c}2.49 \pm 0 . \\
02\end{array}$ \\
\hline $\mathbf{6}$ & $\begin{array}{c}\text { Streptokina } \\
\text { se }\end{array}$ & \multicolumn{3}{|c|}{$8.5 \pm 0.02$} & \multicolumn{3}{|c|}{$7.5 \pm 0.03$} \\
\hline $\mathbf{7}$ & Heparin & \multicolumn{3}{|c|}{$8.9 \pm 0.01$} & \multicolumn{3}{|c|}{$0.9 \pm 0.01$} \\
\hline $\mathbf{8}$ & $\begin{array}{c}\text { Distilled } \\
\text { water }\end{array}$ & \multicolumn{3}{|c|}{$0.9 \pm 0.01$} & & \multicolumn{3}{|c|}{$0.5 \pm 0.01$} \\
\end{tabular}

Positive control: Streptokinase and Heparin

Negative control: Distilled water.

\section{Percentage Clot Lysis Of Coriandrum sativum Varieties}

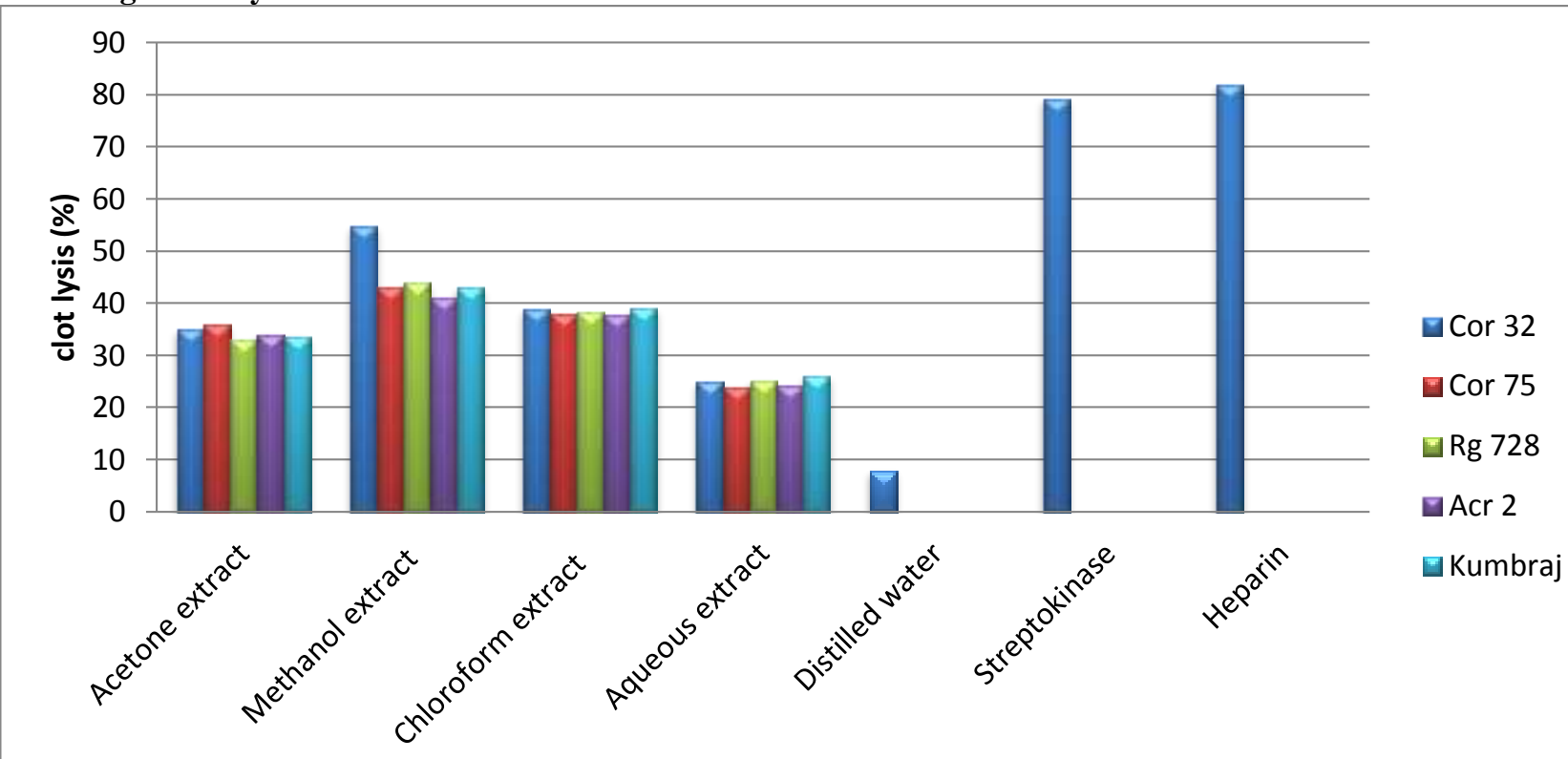

Negative control: distilled water; positive control:Streptokinase and Heparin.

Figure 1:Percentage clot lysis of $C$. sativum varieties (Cor 32, Cor 75, Acr 2, RG 728, Cor 75) 


\section{References:-}

1. Astrup, T.S. and Mullertz, S. (1952): The Fibrin Plate Method for Estimating Fibrinolytic Activity. Arch. Biochem. Biophy., 40: 346-351.

2. Bazzano, L.A., He, J., Ogden, L.G., Loria, C.M., Vupputuri S., Myers L. and Whelton, P.K. (2002): Fruit and vegetable intake and risk of cardiovascular disease in US adults: the first National Health and Nutrition Examination Survey Epidemiologic Follow-up Study. Am. J. Clin. Nutr., 76: 93-99.

3. Harborne, S.B. (1984): A Guide to Modern Techniques of Plant Analysis, Chapman and Hall, London. p. 4.

4. Khan, M.R. and Zehra, H. (2011): Amelioration of CCl (4)-induced nephrotoxicity by Oxalis corniculata in rat. Exp. Toxicol. Pathol., 65(3):327-34.

5. Mahajan, P.M., Nayak, S. and Lele, S.S. (2012): Fibrinolytic enzyme from newly isolated marine Bacillus subtilis ICTF-1: media optimization, purification and characterization. J. Biosci. Bioeng., 113: 307-314.

6. Mahendra, P., Bisht, S. (2011): Coriandrum sativum: A Daily se Spice with Great Medicinal Effect. Pharmacognosy J., 3(21): 84-88.

7. Mandal, S., and Mandal, M. (2015): Coriander (Coriandrum sativum L.) essential oil: Chemistry and biological activity. Asian. Pac. J. Trop. Biomed., 5(6): 421-428.

8. Nascimento, T.P., Sales, A.E., Porto, C.S., Brandao, R.M.P., Takaki, G.M.C., Teixeira, J.A.C., Porto, T.S. and. Porto, A.L.F. (2015): Production and Characterization of New Fibrinolytic Protease from Mucor subtillissimus UCP 1262 in Solid-State Fermentation. Advan. Enz. Res., 3: 81-91.

9. Paulswamy, S. and Jeeshan, M.V. (2011): Preliminary phytochemistry and antimicrobial studies of an endangered medicinal herb Exacum biocolor Roxb. Res. J. Pharm. Biol. Chem. Sci., 2(4): 447-457.

10. Prasad, S., Kashyap, R.S., Deopujari, J.Y., Purohit, H.J and Daginawala, H.F. (2007): Effect of Fagonia Arabica (Dhamasa) on in vitro thrombolysis, BMC. Complement. Altern. Med. 7(36) doi:10.1186/14726882-7-36

11. Rahman, M.A., Sultana, R., Emran, T.B., Islam, M.S., Rahman, M.A., Chakma, J.S., Rashid, H. and Hasan, C.M.M. (2013): Effects of organic extracts of six Bangladeshi plants on in vitro thrombolysis and cytotoxicity. BMC. Complement. Altern. Med., 13:25.

12. Shahwar, M.K., El-Ghorab, H., Anjum, F.M., Butt, M.S., Hussain, S., Nadeem, M. (2012): Characterization of coriander (Coriandrum sativum L.) seeds and leaves: volatile and non volatile extracts. Int. J. Food. Prop., 15: 736-47.

13. Sharma, A. and Sharma, A. (2017): Screening of Citrobacter sp. for fibrinolytic protease production isolated from River Narmada. Inter. J. Adv. Res. Dev., 2(6): 721-725.

14. Sharma, A., Patel, V.K., Rawat, S., Ramteke, P. and Verma, R. (2010): Identification of the antibacterial component of some Indian medicinal plants against Klebsiella pneumonia, Int. J. Parma. Sci. 2 (3).

15. Silva, G.M.M., Bezerra, R.P., Teixeira, J.A., Silva, F.O., Correia, J.M., Porto, T.S., Lima-Filho, J.L. and Porto, A.L.F. (2016): screening, production and biochemical characterization of a new fibrinolytic enzyme produced by Streptomyces Sp. (Streptomycetaceae) isolated from Amazonian Lichens. Acta. Amazonica., 46(3): $301-310$.

16. Simkhada, J.R., Mander, P., Cho, S.S., Yoo, J.C. (2010): A novel fibrinolytic protease from Streptomyces sp. CS684. Proc Bioch. 45: 88-93.

17. Sofowora, E.A. (1993): Medicinal and traditional medicine in Africa. (3rd edn). Spectrum books limited, Nigeria. ; p. 9.

18. Vasanthi, H.R. and Parameswari, R.P. (2010): Indian Spices for Healthy Heart - An Overview. Curr. Cardio. Rev., 6: 274-279. 